\title{
ŠIUOLAIKINIS GALVOS IR KAKLO SRITIES HEMANGIOMU GYDYMAS
}

\author{
Nora Šiupšinskienè $\dot{e}^{1,2}$, Agnẻ Pašvenskaitė ${ }^{2}$, Sigutė Norkiene் $\dot{e}^{1,3}$ \\ ${ }^{1}$ Klaipédos universiteto Sveikatos moksly fakultetas, \\ ${ }^{2}$ Lietuvos sveikatos moksly universiteto ligoninè Kauno klinikos, Ausu, nosies ir gerklès ligu klinika, \\ ${ }^{3}$ Klaipédos jürininku ligoninè
}

Raktažodžiai: hemangioma, galva ir kaklas, konservatyvus gydymas, chirurginis gydymas, propranololis.

\begin{abstract}
Santrauka
Hemangioma - tai dažniausiai pasireiškiantis nepiktybinis navikas galvos ir kaklo srityje. Iki šiolei pirmo pasirinkimo vaistas gydant šios srities hemangiomas buvo peroraliniai kortikosteroidai, tačiau nauji tyrimai pagrindžia $\beta$ blokatorių veiksmingumą. Straipsnyje aptariami šiuolaikiniai galvos ir kaklo hemangiomy konservatyvaus gydymo principai bei intervencinès procedūros. Pristatomi dviejų suaugusių moterų, kurioms diagnozuotos hemangiomos ryklès bei liežuvio šaknies srityse, klinikiniai atvejai.
\end{abstract}

\section{Ivadas}

Hemangioma (HA) - tai kraujagyslinis nepiktybinis navikas, dažniausiai pasireiškiantis antrą - dešimtą gyvenimo savaitę 2,5 proc. naujagimių [1]. HA atsiranda dèl per greito kraujagyslių išvešèjimo, kuris neatitinka audinio ir organo vaskuliarizacijos poreikio ir nèra pateisinamas fiziologiškai. Dažniau HA pastebimos moterims (moterų ir vyrų santykis=2:1) [2].

Nors HA dažniausiai pasireiškia vaikams, jos gali atsirasti ir vyresniame amžiuje - paprastai vyresniems nei 40 metų pacientams [3]. HA, pasireiškiančios suaugusiems, yra mažesnès palyginus su vaikų, tačiau pasitaiko ir didelių, susitelkusių i grupeles HA atvejų. Suaugusiujjų HA atsiradimo priežastis nèra aiški - keletas teorijų teigia genetinę kilmę ar HA atsiradimą dèl nuolat dirginančių cheminių medžiagų [3].

Iki šiolei nusistovejjusios ir vieningos HA klasifikacijos nèra. Klinikiniame darbe priimtiniausia yra histologine - susiformavimo klasifikacija, pagal kurią HA skirstomos ị keletą kategorijų: 1) pagal kraujagyslinę sandarą - ị kapiliarines, kavernines, arteriovenines; 2) pagal atsiradimo laiką - i igimtas ir infantilines (1 lentelè) [4-7]. Infantilinè HA - tai gerybinis navikas, kuris gali pranykti savaime. Skiriamos 3 infantilinès HA fazès: 1) darinio vešèjimo fazé, 2) tylioji fazè, 3) susiformavusio darinio fazè [4]. Paprastai infantilinè HA pasireiškia ne iškarto - stebima greita jos vešẻjimo fazè 1-2-ą ir 4-5-ą mènesius po gimimo [4]. HA vešejimas anksyvosiose fazèse gali būti greitas ir nenuspèjamas, todèl nedelsiant pradètas gydymas gali užkirsti kelią tolimesniam jos vystymuisi [5].

Šio darbo tikslas buvo atlikti mokslo literatūros, skirtos galvos ir kaklo srities hemangiomų gydymui, analizę ir aprašyti du klinikinius suaugusiujų ryklès hemangiomų atvejus.

Galvos ir kaklo srities hemangiomų gydymo būdų apžvalga

Atsižvelgiant ị HA dydị, susiformavimo vietą, komplikacijas, vystymosi fazę, išplitimą ị šalia esančius organus ir psichologinius aspektus, parenkamas individualus gydymas. Pirmiausia taikomas aktyvus paciento sekimas ir konservatyvus gydymas, ir tik retais atvejais pirmo pasirinkimo gydymas yra chirurginis [8].

Konservatyvūs gydymo būdai - kortikosteroidai ir $\beta$ blokatoriai. Daugiau kaip 30 metų pirmo pasirinkimo vaistai HA gydyti buvo peroraliniai kortikosteroidai (KS), kuriu efektyvumas būna iki 84 proc. [9]. Tyrimai rodo, kad geriamasis prednizolonas yra efektyvesnis nei metilprednizolonas [8]. Dažniausiai prednizolono skiriama gerti 3-5 mg/kg kas antrą rytą nuo 6 iki 8 savaičių; po to vaisto dozė palaipsniui mažinama dvi-tris savaites - iki visiško vaisto nutraukimo. Gydymas gali būti kartojamas dviem ar trimis ciklais su 4-6 savaičių pertraukomis [10]. Geriausi rezultatai stebimi gydant jaunesnius nei 6 mėnesių amžiaus vaikus - kuo vyresnis pacientas, tuo rezultatai prastesni [8].

Pirmą kartą efektyvus $\beta$ blokatorių taikymas, gydant HA, aprašytas 2008 metais [11]. Tyrimai atskleide, kad po nesèkmingo gydymo KS, stebimas efektyvus gydymas $\beta$ blokatoriais - propranololiu [12]. Sanchez-Carpintero ir ben- 
draautoriai pateikia duomenis, kad, gydant segmentines HA propranololiu, gaunamas geresnis gydymo atsakas nei jas gydant KS [4]. Tačiau gydant židinines HA, propranololis ir KS, ypač jei KS taikomi injekcijomis, yra vienodai efektyvūs [4]. Mažoms, paviršinèms kūdikių HA gydyti gali būti vietiškai naudojami KS tepalai - 0,05 proc. klobetazolio proprionatas [13].

Nauji moksliniai tyrimai parode, kad, gydant propranololiu jauno amžiaus vaikų HA, labai geri rezultatai gaunami ir proliferacineje, ir susiformavimo HA fazèse, kai tuo tarpu KS yra veiksmingi tik proliferacinèje fazèje [14-16]. Pateiktų

1 lentelè. Hemangiomų klasifikacija [4-7]

\begin{tabular}{|c|c|c|}
\hline \multicolumn{3}{|l|}{ Hemangiomos } \\
\hline \multirow[t]{4}{*}{$\begin{array}{l}\text { 1) Pagal } \\
\text { kraujagyslinę } \\
\text { sandarą }[4,6] \text { : }\end{array}$} & \multirow[t]{2}{*}{$\begin{array}{l}\text { a) Kapilia- } \\
\text { rinès }\end{array}$} & $\begin{array}{l}\text { Pagal išvaizdą: } \\
\text { • Naujagimių - „,braškinės” } \\
\text { - Suaugusiujų - „vyšninės“. Tai amžinis pa- } \\
\text { kitimas, pasireiškiantis ant liemens, galūniu, } \\
\text { vèliau atsiranda veide kaip 1-5 mm skersmens } \\
\text { vyšninis mazgelis. }\end{array}$ \\
\hline & & $\begin{array}{l}\text { Pagal reljefą: } \\
\text { - egzofitinès (smulkiai grublètos, truputị iš- } \\
\text { kilusios) } \\
\text { • telangiektazinès (tankios, smulkios, išsi- } \\
\text { plètusios, neiškilusios). }\end{array}$ \\
\hline & $\begin{array}{l}\text { b) Kaverni- } \\
\text { nès }\end{array}$ & $\begin{array}{l}\text { Apima dermą ir iš dalies paodị, esti kempinès } \\
\text { struktūros, melsvai raudonos ar rudos spalvos. } \\
\text { Paviršius yra lygus ar truputi gumbuotas dè } \\
\text { ịvairaus didumo ertmių. Kaverninès HA būna } \\
\text { asocijuotos su galvos bei nugaros smegenu, } \\
\text { kaulų, kraujodaros organų patologija ir ịeina } \\
\text { ị kelių sindromų sudètị (Phace sindromas, } \\
\text { Kasabach Merrit sindromas). }\end{array}$ \\
\hline & $\begin{array}{l}\text { c) Arterio- } \\
\text { veninès }\end{array}$ & $\begin{array}{l}\text { Labai retos. } \\
\text { Pagal tai, kokios kraujagyslès yra pažeistos, } \\
\text { jos gali būti: } \\
\text { • subliuškusios, lengvai suspaudžiamos (ve- } \\
\text { ninės) } \\
\text { - kietos, elastingos, pulsuojančios (arterinès). }\end{array}$ \\
\hline \multirow[t]{2}{*}{$\begin{array}{l}\text { 2) Pagal atsi- } \\
\text { radimo laiką } \\
{[4,7] \text { : }}\end{array}$} & $\begin{array}{l}\text { a) Infantili- } \\
\text { nès HA: }\end{array}$ & $\begin{array}{l}\text { - Židininės - arškiu ribų, dažniausiai ovalios } \\
\text { formos, nesusijusios su raidos sutrikimais. } \\
\text { - Segmentinès - užima plačią anatominę sriț, } \\
\text { primena ,„̌̌emėlapi”, susijusios su raidos su- } \\
\text { trikimais. } \\
\text { - Neapibrěžtos }\end{array}$ \\
\hline & $\begin{array}{l}\text { b) Igimtos } \\
\text { HA: }\end{array}$ & $\begin{array}{l}\text { - Greitai susiformuojančios HA (angl. RICH } \\
\text { (rapid involuting congenital hemangioma) - } \\
\text { pasireiškia tik gimus kūdikiui ir palaipsniui } \\
\text { didejja per kelis pirmuosius menesius. } \\
\text { - Iškart susiformavusios HA (angl. NICH } \\
\text { (noninvoluting congenital hemangioma) - } \\
\text { pasireiškia iškart gimus kūdikiui ir nedidèja } \\
\text { palaipsniui. }\end{array}$ \\
\hline
\end{tabular}

tyrimų duomenimis, gydymas propranololiu daugeliu atvejų yra veiksmingesnis nei gydymas KS, kai abu preparatai vartojami tiek pat laiko [14].

Geriamasis propranololis yra visiškai absorbuojamas ir aukščiausią koncentraciją kraujo plazmoje pasiekia po 1-2 valandų. Daugiau nei 90 proc. propranololio yra metabolizuojama kepenyse, o vaisto skilimo pusperiodis yra 3-6 valandos. Vaistą rekomenduojama vartoti kas 8 valandas [4]. Propranololis greitai pasiskirsto audiniuose, pasiekdamas aukštą koncentraciją plaučiuose, kepenyse, smegenyse, galvos ir kaklo srityje ir širdyje. Literatūroje pateikiama nemažai skirtingų propranololio dozavimo schemų, tačiau dažniausiai šis prepratas skiriamas $1-3 \mathrm{mg} / \mathrm{kg}$ per parą, dozę suvartojant per 3 kartus [12-21]. Propranololis vartojamas tol, kol gaunamas teigiamas gydymo rezultatas. Kadangi nèra paruoštos specialios geriamosios propranololio formos kūdikiams, vaistas gali būti ištirpinamas sirupe [4].

Sèkmingi geriamojo propranololio rezultatai leido daryti prielaidą, kad mažos, paviršinès hemangiomos gali būti gydomos šiuos vaistus naudojant vietiškai. Tyrimai parode, kad 0,5 proc. timololio maleato tepalas naudojamas 2 kartus per dieną 5 savaites, reikšmingai sumažina HA dydị, standumą ir pigmentaciją [22].

Reikia atminti, kad pagrindinès - oficialiosios indikacijos propranololio vartojimui yra arterinè hipertenzija, krūtinès angina, ūmus miokardo infarktas, aritmijos, širdies nepakankamumas, padidejjusi skydliaukès veikla. Propranololis taip pat yra vartojamas nerimui mažinti, gydyti glaukomą ar migrenos profilaktikai [4].

Kadangi vaisto informaciniame lapelyje HA gydymas nèra nurodytas, pacientams reikia detaliai paaiškinti apie vaisto efektyvumą ir saugumą. Taip pat būtina atminti, kad prieš pradedant HA gydymą propranololiu, būtina kardiologo konsultacija dèl vaisto vartojimo kontraindikacijų, galimo nepageidaujamo poveikio ịvertinimo ir individualios dozuotès parinkimo.

Propranololis yra kontraindikuotinas pacientams, turintiems antro ar trečio laipsnio atrioventrikulinę blokadą, progresuojantị ar nestabilų širdies nepakankamumą, bradikardiją, hipotenziją, sinusinio mazgo ligas bei astmą [4]. Tyrimais nustatyta, kad nepageidaujamas 
$\beta$ blokatorių poveikis yra labai retas. Jis gali pasireikšti hipotenzija, bradikardija, staziniu širdies nepakankamumu, dusuliu, nuovargiu, miego sutrikimais (košmarai, nemiga), parestezijomis, pykinimu ir galvos svaigimu, depresija ir kitais psichologiniais sutrikimais, trombocitopenija, haliucinacijomis, alopecija, šaltomis galūnemis [4]. Taip pat $\beta$ blokatoriai gali sukelti hipoglikemiją, periferinių kraujagyslių vazokonstrikciją (Raynaud sindromą).

Atsižvelgiant ị iki šiolei atliktų vaikų ir suaugusiujų HA gydymo propranololiu tyrimų duomenis, nepageidaujamas poveikis pastebetas tik keliems vaikams: 2 vaikams pasireiškẻ hipoglikemija ir hipotermija [19], taip pat užfiksuoti keli bradikardijos atvejai [20]. Taigi, geriamasis propranololis yra veiksmingas ir saugus vaistas skirtingo amžiaus pacientams $[17,18]$.

Tyrimu su kitais $\beta$ blokatoriais, gydant HA, atlikta nedaug. Blanchet ir bendraautoriai pateike gerus rezultatus gydant poklostines HA geriamuoju acebutololiu: gydymas buvo veiksmingas 2 iš 3 pacientų [23]. Rekomenduojama acebutololio dozè - $2 \mathrm{mg} / \mathrm{kg}$ per parą, dozę suvartojant per du kartus; vẻliau dozę galima didinti iki 8-10 mg/kg per parą.

Kai HA gydymas KS ar $\beta$ blokatoriais nèra efektyvus, atsižvelgiant ị pažeidimo vietą, gylị ir išplitimą, gali būti taikomi kiti konservatyvūs gydymo būdai.

Triamcinolono injekcijos. Šis gydymo būdas indikuotinas pacientams, kuriems HA yra išplitusios i gretimas struktūras, (pvz., ị akibuodę, seilių liauką). Gali būti skiriamos $1-2 \mathrm{mg} / \mathrm{kg}$ triamcinolono injekcijos, kurios injekuojamos ị pažeidimo vietą kas mènesị; maksimali vienkartinè preparato dozè negali viršyti $60 \mathrm{mg}$ [24].

Imikvimodo aplikacijos. Gerai matomoje vietoje esančios smulkios ir vidutinio dydžio HA gali būti gydomos imuninio atsako moduliatoriumi - imikvimodu, kuris naudojamas vietiškai kas antrą parą, $3-5$ mènesius [25]. Šio preparato privalumas - tai paprastas ir saugus naudojimas, nesukeliant sisteminio poveikio. Kai kuriems pacientams imikvimodo aplikacijos gali sukelti hiperpigmentaciją, todèl šis preparatas turètų būti atsargiai naudojamas veido srities HA gydyti [25].

Alfa interferonas. Alfa interferonas taip pat yra efektyvus preparatas, gydant HA, tačiau dèl galimos spastinès displegijos grèsmès taikomas itin atsargiai ir tik esant neveiksmingam gydymui kitais, aukščiau aptartais preparatais [26].

Pingiangmicino injekcijos. Dèl ypač stipraus kraujagyslių endotelio sklerozuojančio poveikio yra vartojamos pingiangmicino (bleomicino A5) injekcijos, kurios veiksmingos daugiau nei 90 proc. atvejų [27]. Pingiangmicino injekcijos dažniausiai vartojamos gydyti proliferacines, komplikuotas ir sunkiai pasiduodančias gydymui kitais būdais - KS ar lazeriu, HA [28]. Injekcijoms vartojamas 2 proc. lidokaine ištirpintas pingiangmicino hidrochloridas ( $8 \mathrm{mg}$ švirkšte), kuris vẻliau sumaišomas su fiziologiniu tirpalu ir deksametazonu $(5 \mathrm{mg} /$ $\mathrm{ml})$. Injekcinè adata nukreipiama link kraujagyslinio darinio centro pamažu keičiant kryptị ir siekiant infiltruoti visą darini iki jis pabąla. Vèliau pažeidimo vieta spaudžiama apie 1530 minučių. Injekcijos gali būti kartojamos kas 2-3 savaites, neviršijant maksimalios vienkartinès $8 \mathrm{mg}$ pingiangmicino hidrochlorido dozès, o kūdikiams - 1/4 - 2/3 maksimalios dozès. Paviršinėms odos ar gleivinių HA gydyti gali būti taikoma $1 \mathrm{mg} / \mathrm{ml}$ pingiangmicino hidrochlorido koncentracija, o poodinėms ir gilesnių sluoksnių HA - 1,5-2 mg/l [28].

Vinkristino injekcijos. Atsparioms gydymui KS ar atsinaujinusioms HA gydyti gali būti taikomas gydymas vinkristinu. Skiriamos intraveninès $0,5-1 \mathrm{mg} / \mathrm{kg}$ vinkristino injekcijos 1 kartą per savaitę, 6 savaites. Prireikus ciklas gali būti kartojamas [29].

Chirurginiai gydymo būdai. Lazerinė terapija. Paviršinėms, aiškiai ribotoms, proliferuojančioms HA gydyti gali būti taikoma lazerinè terpija [8]. Šis gydymo būdas gali pagreitinti kraujagyslinio darinio regresiją, sumažinant naviko dydị bei sudaryti palankesnes sąlygas vẻliau taikyti kitus gydymo būdus [30]. Jeigu taikant gydymą lazeriu stebimas HA vešejimas, tuomet iš karto kartu skiriamas gydymas vaistais (KS ar $\beta$ blokatoriais). Gydymas lazeriu yra nesudètingas, procedūrą galima kartoti kas $2-4$ savaites, o gydymo veiksmingumas pakankamas, tačiau procedūroms atlikti reikia specialios aparatūros [8]. Blykstès lempos indukuojamo dažų lazerio (angl. Flash lamp-pumped pulsed dye laser) bangos ilgis siekia nuo 585 iki $595 \mathrm{~nm}$, o tai leidžia sukelti selektyvią kraujagyslių destrukciją atliekant pasirinktos kraujagyslès fotokoaguliaciją ir nepažeisti dengiančio odos/gleivinès sluoksnio. Dẻl riboto įsiskverbimo gylio šis lazeris nèra efektyvus poodiniame ir gilesniuose sluoksniuose išsidèsčiusioms HA gydyti [8]. Itrio aluminio granato, legiruoto neodimio jonais, lazerio (angl. Neodymium: yttrium-aluminum-garnet (Nd:YAG) laser) bangos ilgis yra $1064 \mathrm{~nm}$, o ịsiskverbimo gylis siekia iki $5 \mathrm{~mm}$, todèl šis lazeris gali būti panaudotas didesnèms ir gilesnèms HA gydyti [8]. Gydymo efektyvumas, taikant lazerinę terapiją, siekia nuo 77 proc. iki 100 proc. Tyrimais nustatyta, kad kuo pažeidimas mažesnis, tuo gydymo rezultatai geresni [8]. Negaunant norimo efekto ir per ilgai taikant lazerinę terapiją, galima sukelti audinių nekrozę, taip pat gali susiformuoti didesni randai [31]. Nors skirtingų lazerių panaudojimas yra efektyvus gydant HA, tačiau pirmo pasirinkimo gydymas turètų būti KS ar $\beta$ blokatoriai [8].

Radikalus chirurginis gydymas. Radikalus chirurginis gydymas skiriamas, kai konservatyvus gydymas KS ir/ar $\beta$ blokatoriais yra neveiksmingas. Negausūs klinikiniai tyrimai rodo, kad šis gydymo būdas yra veiksmingesnis nei lazerinè 
terapija [8]. Dažniausiai ankstyvas chirurginis gydymas yra taikomas, kai gerybinis kraujagyslinis darinys apima gerklas ar trachëją (siekiant išvengti kvėpavimo takų obstrukcijos), kai yra sutrikęs regejjimas (išplitimas ị akies vokus) ar kai yra šalia esančių organų destrukcija [32]. Tradicinis chirurginis gydymas taip pat taikomas kai reikia pašalinti jau gydytos HA defektą, kai liga atsinaujina ar sunkiai pasiduoda

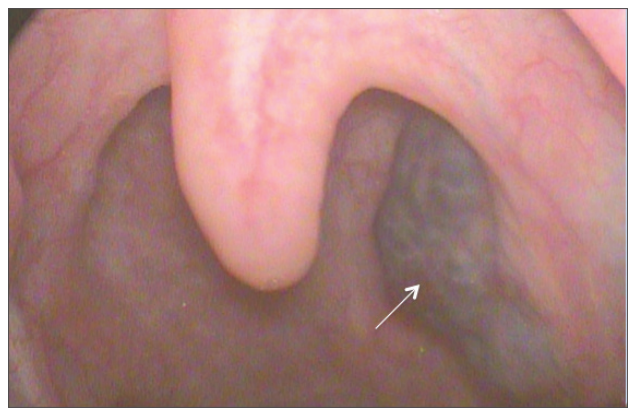

1 pav. Pacientès K.A. burnaryklès vaizdas. Hemangioma kairejje ryklès pusèje parodyta rodykle

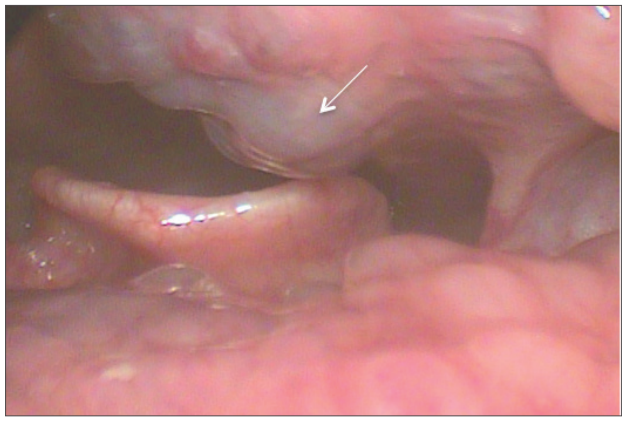

2 pav. Pacientės K.A. gerklaryklès vaizdas. Stebimas hemangiomos kontaktas su antgerkliu (patologija parodyta rodykle)

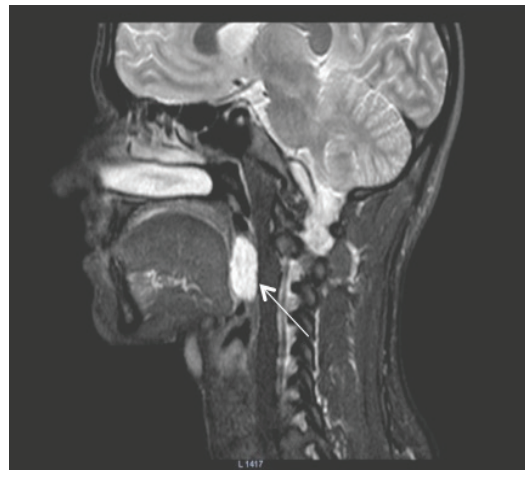

3 pav. Pacientės K.A. galvos ir kaklo srities MRT- sagitalinis pjūvis; hemangioma ryklès srityje parodyta rodykle

gydymui kitais būdais [8]. Prieš nusprendžiant taikyti chirurgini gydymą, būtina įvertinti, ar planuojamas rezultatas bus kosmetiškai palankesnis nei gydymas vaistais ir paciento intensyviu sekimu.

Indikacijos chirurginiam HA gydymui: 1) HA, esančios nosies galiuko ir lūpų srityje, kai nèra efekto taikant konservatyvius gydymo būdus; 2) HA, esančios akių vokų srityje ir sukeliančios regéjimo suprastejimą; 3) HA, esančios kaktos srityje; 4) kai pasikartoja kraujavimas iš HA [8].

Grèsmingų hemangiomų gydymo taktika. Periorbitalinès hemangiomos gydymas. HA, išsidèstančios aplink akị, turètų būti gydomos kuo anksčiau. Net jeigu regèjimas yra sutrikęs iki 2 savaičių, gali išsivystyti negrịžtami pakitimai. Anksčiau pirmo pasirinkimo gydymas buvo geriamieji ar injekcijomis skiriami KS, tačiau šiuo metu rekomenduojama gydymą pradèti $\beta$ blokatoriumi - propranololiu. Dauguma tyrimų rodo, kad pradejus vartoti propranololi, darinys suma$\begin{array}{lll}5 \text { pav. Pacientės R.B. gerklaryklès vaizdas. I̦ he- } & \text { žèja greitai - per } 48-72 \\ \text { mangiomą panašus darinys kairèje liežuvio šaknies } & \text { valandas nuo gydymo }\end{array}$ pusèje parodytas rodykle

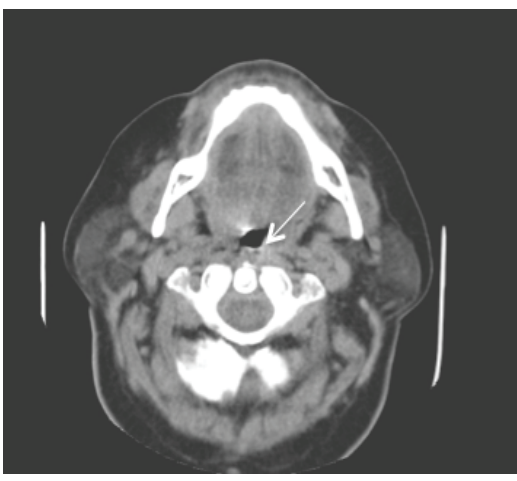

6 pav. Pacientès R.B. galvos ir kaklo srities KT. Išsiplètusi kraujagyslè kairèje liežuvio šaknies pusejje parodyta rodykle

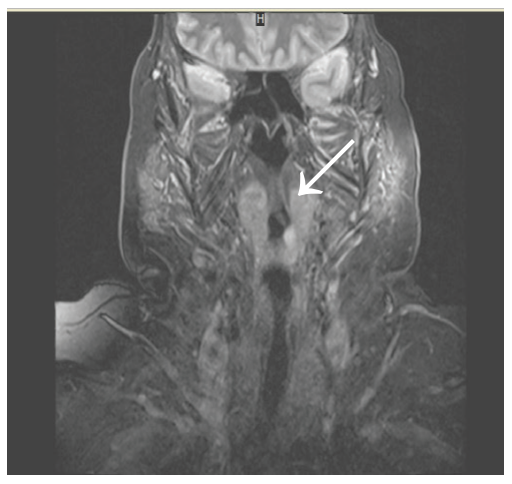

7 pav. Pacientès R.B. galvos ir kaklo srities MRT. Hemangioma kairèje liežuvio šaknies pusejje parodyta rodykle 
pradžios [33]. Gydymo veiksmingumas, vartojant propranololị 1 mènesị, siekia iki 82 proc. atvejų[15].

Kvėpavimo takų (gerklų ir trachėjos) hemangiomos gydymas. Galvos ir kaklo hemangiomos, sukeliančios pavojų kvėpavimo takų praeinamumui, dažniausiai yra paviršinès ir vienpusès. Siekiant užtikrinti kvejpavimo takų praeinamumą, gali tekti atlikti tracheostomiją ar greitą darinio pašalinimą lazeriu [34]. Tačiau dauguma autorių pateikia sẻkmingus HA, esančių kvejpavimo takuose, gydymo propranololiu rezultatus [35]. Leboulager ir bendraautoriai pateikia sẻkmingus 14 pacientų, gydytų propranololiu, duomenis: kvèpavimo takų obstrukcija po 2 savaičiu gydymo buvo išlikusi tik 22 proc. pacientu, o po 4 savaičiu -88 proc. tiriamuju pasveiko [36]. Anksčiau atliktuose tyrimuose, gydant HA kvejpavimo takuose, kartu su propranololiu dažnai buvo skiriami KS, tačiau pastarojo meto tyrimai leidžia daryti išvadą, kad dviejų preparatų vartojimas nèra racionalus, todèl rekomenduojama rinktis vieną preparatą, pirmiau renkantis propranololi [37]. Literatūroje taip pat yra duomenų apie sèkmingą hemangiomų kvėpavimo takuose gydymą kitu $\beta$ blokatoriumi - acebutololiu, kurio skiriama $2 \mathrm{mg} / \mathrm{kg}$ per parą, dozę padalinant per 2 kartus [23].

\section{Klinikiniai atvejai}

\section{I klinikinis atvejis - ryklès hemangioma.}

28 metų moteris (K.A.) atvyko ị Lietuvos sveikatos mokslų universiteto ligoninès Kauno klinikų (LSMUL KK) Ausų, nosies ir gerklès ligų konsultacinę polikliniką dèl pasunkejjusio rijimo, atsiradusio darinio ryklèje. Skundai tęsèsi apie 3 mènesius. Pacientei atlikta vaizdolaringoskopija (VLS) - burnaryklèje, kairèje už gomurinès tonzilès stebètas melsvas, $\mathfrak{i}$ hemangiomą panašus darinys, užimantis dali užpakalinès ryklès sienos ir užpakalinį žiočių lanką (1 pav.). Darinys kontaktavo su antgerkliu (2 pav.).

Atlikto magnetinio rezonanso tyrimo (MRT) išvada burnaryklès kairèje pusèje, mukoziniame tarpe, ties gomurine tonzile, matomas apie 2,2 x 1,5 cm dydžio, gana aiškių ribų, ne visai homogeniškos skylètos struktūros, intensyviai kontrastinę medžiagą kaupiantis darinys, deformuojantis burnaryklę iš kairès ir siaurinantis jos spindị ( 3,4 pav.). Pakitimai panašūs ị burnaryklès HA.

Ivertinus klinikinius ir MRT duomenis, pacientei nustatyta diagnozè - kairiosios ryklès pusès hemangioma (lot. hemangioma pharyngis lateris sinistri).

Pacientè konsultuota kardiologo dèl planuojamo gydymo propranololiu. İvertinus pacientès būklę ir nesant kontraindikacijų, paskirtas gydymas propranololiu $-25 \mathrm{mg}$ du kartus per dieną. Po 2 mènesių, susisiekus telefonu, nes pacientè išvyko gyventi ị užsieni, moteris išsakè, kad rijimas sunormalejo, darinio nejaučianti.
II klinikinis atvejis - liežuvio šaknies hemangioma. 68 metų moteris (R.B.) kreipèsi į LSMUL KK Ausų, nosies ir gerklès ligų konsultacinę polikliniką dėl knarkimo ir kartais pasirodančio kraujo stipriai kosint. Atlikta vaizdolaringoskopija - kairèje liežuvio šaknies pusèje stebėtas i hemangiomą panašus darinys, kartu buvo matyti išvešėjęs liežuvinès tonzilès audinys ( 5 pav.)

Pacientei atliktas KT tyrimas su kontrastu. KT tyrimo išvada - liežuvio tonzilè nelygiu paviršiumi siaurina valekules, kairiosios tonzilès paviršiumi praeina nedidelè paviršinė kraujagyslès šakute (6 pav.). Diagnozės patikslinimui, diferencijuojant tarp skirtingų liežuvio navikų, tikslingas MRT tyrimas.

Atlikto MRT išvada: liežuvio šaknies kairèje pusèje matomas gana aiškių ribų, intensyviai kontrastinę medžiagą kaupiantis darinys. Pakitimai panašūs ị liežuvio šaknies HA (7 pav.).

Po kardiologo konsultacijos, pacientei paskirtas gydymas propranololiu - $25 \mathrm{mg}$ du kartus per dieną tris mènesius ir aktyvus ambulatorinis sekimas. Pacientę sekant 8 ménesius - darinys nedidèja, kraujavimo epizodų nebuvo.

\section{Išvados}

Šiuolaikiniai tyrimai rodo, kad geriamieji $\beta$ blokatoriai (propranololis) gali būti pirmo pasirinkimo vaistas gydant skirtingo amžiaus galvos ir kaklo srities HA. Prieš paskiriant gydymą $\beta$ blokatoriais, būtina kardiologo konsultacija. Chirurginis HA gydymas indikuotinas, kai gydymas vaistais yra neveiksmingas arba kai stebimi komplikuoti HA atvejai. Reikalingi tolimesni, ypač suaugusiujjų, tyrimai, vertinantys konservatyvaus ir chirurginio gydymo veiksmingumą.

\section{Literatūra}

1. Holmdahl K. Cutaneous hemangiomas in premature and mature infants. Acta Paediatr 1955;44:370-379. https://doi.org/10.1111/j.1651-2227.1955.tb04151.x

2. Pauliukas $P$. Chirurgiškai išgydyto akiduobès kraujagyslinio auglio (kaverninès hemangiomos) klinikinis atvejis. Gydymo menas, 2001;10(73):82-84.

3. Wang X, ZHAO X, Zhu W. Resection of a laryngeal hemangioma in an adult using an ultrasonic scalpel: a case report. Oncology letters 2015;9;2477-2480.

4. Sanchez-Carpintero I, Ruiz-Rodriguez R, Lopez-Gutierrez JC. Propranolol in the treatment of infantile hemangioma:clinical effectiveness, risks, and recommendations. Actas Dermosifiliogr 2011;102(10):776-779.

https://doi.org/10.1016/j.ad.2011.05.003

5. Sánchez-Carpintero I, Waner M, Mihm MC. Hemangiomas infantiles. In: Torres Losada V, Camacho FM, Sober A, Mihm MC, Sánchez-Carpintero I, editors. Dermatología Prác- tica Ibero-latinoamericana. Cali: Ediciones Nieto 2005; 1284-1305. 
6. Ballah D, Cahill AM, Fontalvo L. et al. Vascular anomalies: what they are, how to diagnose them, and how to treat them. Curr Probl Diagn Radiol 2011;40:233-247. https://doi.org/10.1067/j.cpradiol.2011.04.001

7. Robert GK, Krishna GP. Evidence-based medicine in the treatment of infantile hemangiomas. Facial Plast Surg Clin Am 2015;2:373-392.

8. Zheng WJ, Zhou Q, Yang JX. et al. Treatment guideline for hemangiomas and vascular malformations of the head and neck. Published online 2009 in Wiley InterScience

9. Bennett ML, Fleischer AB Jr, Chamlin SL, Frieden IJ. Oral corticosteroid use is effective for cutaneous hemangiomas: an evidence-based evaluation. Arch Dermatol 2001;137:12081213.

https://doi.org/10.1001/archderm.137.9.1208

10. Zheng JW, Yang XJ, Zhou Q. et al. Short-term high-dose oral prednisone on alternate days: a more rational re- gime for infantile hemangiomas. Med Hypotheses 2009;72:365.

https://doi.org/10.1016/j.mehy.2008.10.004

11. Léauté-Labrèze C, Dumas de la Roque E, Hubiche T, Boralevi F, Thambo JB, Taïeb A. Propranolol for severe hemangiomas of infancy. New Engl J Med 2008;358:2649-2651. Comment in: N Engl J Med 2008;359:2846; author reply 2846-7; J R Coll Physicians Edinb 2010;40:128-129. https://doi.org/10.1056/NEJMc0708819

12. Manunza F, Syed S, Laguda B. et al. Propranolol for complicated infantile haemangiomas: a case series of 30 infants. $\mathrm{Br}$ J Dermatol 2010;162: 466-468. https://doi.org/10.1111/j.1365-2133.2009.09597.x

13. Garzón MC, Lucky AW, Hawrot A, Frieden IJ. Ultrapotent topical corticosteroid treatment of hemangiomas of infancy. J Am Acad Dermatol 2005;52:281-286. https://doi.org/10.1016/j.jaad.2004.09.004

14. Li YC, McCahon E, Rowe NA, Martin PA, Wilcsek GA, Martin FJ. Successful treatment of infantile haemangiomas of the orbit with propranolol. Clin Experiment Ophthalmol 2010;38: 554-559.

https://doi.org/10.1111/j.1442-9071.2010.02327.x

15. Al Dhaybi R, Milet A, McCuaig C, Ospina L, Powel J. Treatment of periocular infantile hemangiomas with propranolol: a review of 17 cases. Pediatr Dermatol 2010;26:665-666.

16. Truong MT, Perkins JA, Messner AH, Chang KW. Propranolol for the treatment of airway hemangiomas: a case series and treatment algorithm. Int J Pediatr Otorhinolaryngol 2010;74:10431048 .

https://doi.org/10.1016/j.ijporl.2010.06.001

17. Bidabadi E, Mashouf M. A randomized trial of propranolol versus sodium valproate for the prophylaxis of migraine in pediatric patients. Paediatr Drugs 2010;12:269-275. https://doi.org/10.2165/11316270-000000000-00000

18. Love JN, Sikka N. Are 1-2 tablets dangerous? Beta-blocker expo- sure in toddlers. J Emerg Med 2004;26:309-314. https://doi.org/10.1016/j.jemermed.2003.11.015

19. Holland KE, Frieden IJ, Frommelt PC, Mancini AJ, Wyatt D, Drolet BA. Hypoglycemia in children taking propranolol for the treatment of infantile hemangioma. Arch Dermatol 2010;146: 775-778.

https://doi.org/10.1001/archdermatol.2010.158

20. Frieden IJ, Drolet BA. Propranolol for infantile hemangiomas: promise, peril, pathogenesis. Pediatr Dermatol 2009;26: 642644.

https://doi.org/10.1111/j.1525-1470.2009.00977.x

21. Tan ST, Itinteang T, Leadbitter P. Low-dose propranolol for infantile haemangioma. J Plast Reconstr Aesthet Surg 2011;64:292-299.

https://doi.org/10.1016/j.bjps.2010.06.010

22. Guo S, Ni N. Topical treatment for capillary hemangioma of the eyelid using b-blocker solution. Arch Ophthalmol 2010;128:255-256.

https://doi.org/10.1001/archophthalmol.2009.370

23. Blanchet C, Nicollas R, Bigorre M, Amedro P, Mondain M. Management of infantile subglottic hemangioma: acebutolol or propranolol? Int J Pediatr Otorhinolaryngol 2010;74: 959-961. https://doi.org/10.1016/j.ijporl.2010.05.013

24. Gangopadhyay AN, Sharma SP, Gopal SC, Gupta DK, Panjawani K, Sinha JK. Local steroid therapy in cutaneous hemangiomas. Indian Pediatr 1996;33:31-33.

25. McCuaig CC, Dubois J, Powell J. et al. A phase II, open- label study of the efficacy and safety of imiquimod in the treatment of superficial and mixed infantile hemangioma. Pediatr Dermatol 2009;26:203-212.

https://doi.org/10.1111/j.1525-1470.2008.00857.x

26. Ezekowitz RA, Mulliken JB, Folkman J. Interferon alfa- 2a therapy for life-threatening hemangiomas of infancy. N Engl J Med 1992;326:1456-1463.

https://doi.org/10.1056/NEJM199205283262203

27. Muir T, Kirsten M, Fourie P, Dippenaar N, Ionescu GO. Intralesional bleomycin injection (IBI) treatment for haemangiomas and congenital vascular malformations. Pediatr Surg Int 2004; 19:766-773.

https://doi.org/10.1007/s00383-003-1058-6

28. Omidvari S, Nezakatgoo N, Ahmadloo N, Mohamma- dianpanah M, Mosalaei A. Role of intralesional bleomycin in the treatment of complicated hemangiomas: prospective clinical study. Dermatol Surg 2005;31:499- 501.

https://doi.org/10.1097/00042728-200505000-00001

29. Enjolras O, Brevie 're GM, Roger G. et al. Vincristine treatment for function- and life-threatening infantile hemangioma. [Article in French] Arch Pediatr 2004;11:99- 107. https://doi.org/10.1016/j.arcped.2003.10.014

30. Vesnaver A, Dovsak DA. Treatment of vascular lesions in the head and neck using Nd:YAG laser. J Craniomax- illofac Surg 
2006; 34:17-24.

https://doi.org/10.1016/j.jcms.2005.07.009

31. Michel JL. Treatment of hemangiomas with $595 \mathrm{~nm}$ pulsed dye laser dermobeam. Eur J Dermatol 2003;13:136-141.

32. Zheng JW, Zhou GY, Wang YA, Zhang ZY. Management of head and neck hemangiomas in China. Chin Med J (Engl) 2008;121:1037-1042.

33. Jadhav VM, Tolat SN. Dramatic response of propranolol in hemangioma: report of two cases. Indian J Dermatol Venereol Leprol 2010;76:691-694.

https://doi.org/10.4103/0378-6323.72472

34. Rahbar R, Nicollas R, Roger G. et al. The biology and management of subglottic hemangioma: past, present, future. Laryngoscope 2004;114:1880-91.

https://doi.org/10.1097/01.mlg.0000147915.58862.27

35. Rosbe KW, Suh KY, Meyer AK, Maguiness SM, Frieden IJ. Propranolol in the management of airway infantile hemangiomas. Arch Otolaryngol Head Neck Surg 2010;136:658-665.

https://doi.org/10.1001/archoto.2010.92

36. Leboulanger N, Fayoux P, Teissier N. et al. Propranolol in the therapeutic strategy of infantile laryngotracheal hemangioma: a preliminary retrospective study of French experience. Int $\mathrm{J}$ Pediatr Otorhinolaryngol. 2010; 74:1254-1257.

https://doi.org/10.1016/j.ijporl.2010.07.025
37. Maturo S, Hartnick C. Initial experience using propranolol as the sole treatment for infantile airway hemangiomas. Int $\mathrm{J}$ Pediatr Otorhinolaryngol 2010; 74:323-325.

https://doi.org/10.1016/j.ijporl.2009.12.008

\section{MODERN TREATMENT OF HEAD AND NECK HEMANGIOMAS}

N. Šiupšinskienė, A. Pašvenskaitė, S. Norkienė

Key words: hemangioma, head and neck, conservative treatment, surgical treatment, propranolol.

Summary

Hemangioma is the most common benign tumor of the head and neck region. Until recently, corticosteroid therapy was considered as the first choice for the treatment of such tumor, but there are new evidences on the effective treatment with the use of $\beta$-blockers. The article discusses conservative as well as invasive treatment of the head and neck hemangiomas. Two clinical cases of hemangiomas in the otopharynx also in the root of tongue region in adult women are presented.

Correspondence to: norai_s@yahoo.com

Gauta 2017-09-18 